\title{
Thyroid Hormone Concentrations in Nepal: A Study of Potential Gurkha Army Recruits. The Effect of Changes in Diet
}

\author{
Col G E Ratcliffe* \\ $M B, M R C P$, L/RAMC
}

\author{
A Lowry \\ G Mashiter \\ Divn of Radiological Sciences, UMDS, Guy's Hospital, London SE1 9RT
}

M A Smith

Dept of Medical Physics, The University of Leeds, Leeds General Infirmary, Leeds LS1 3EX

A E Young

Dept of Zoology, Bristol University, Woodland Road, Bristol

\author{
M N Maisey \\ Divn of Radiological Sciences, UMDS, Guy's Hospital, London SEI 9RT
}

SUMMARY: A group of non goitrous, potential Gurkha army recruits were tested in Nepal for serum triiodothyronine (f $\mathrm{T}^{3}$ ), free thyroxine (f(T) and thyrotropin (TSH) concentrations. Twenty-five percent of the men ver recruited into the army and urine samples taken for analysis of iodine and creatinine. Twenty per cent of the recretites underwent thyrotropin releasing hormone (TRH) stimulation tests. After ten months basic training on a diet considezed to be iodine sufficient, the tests were.repeated on the same men. The results were also compared to army recruits in the $\vec{E}$ UK. All the potential Gurkha recruits had higher serum levels of thyroid hormones than the UK recruits. Some regiogaif differences were found with those men from the Western recruiting depot having lower fT4 and higher TS! concentrations. Urinary iodine and creatinine concentrations showed evidence of slight relative malnutrition and iodien deficiency which was more pronounced in the Western depot. TRH stimulation tests showed no evidence of thyroi i dysfunction but highlighted the differences between the Eastern and Western groups. After ten months on an ioding sufficient diet the serum thyroid hormone concentrations became closer to those of the UK recruits, showing an? differences to be reversible. The results from the two Gurkha groups became similar which was reflected in the urin? analysis results.

\section{Introduction}

The Himalayan goitre belt runs from North Pakistan in the West to Burma in the East. Nepal lies entirely within this region and is one of the major iodine deficient areas in the world. The high level of endemic goitre and cretinism is an indication of the lack of iodine in the food and water. This is more pronounced in the Northern mountainous areas than in the Terai plains in the South which have less barren soils(1). Within these areas there are differences between East and West, with the West having a higher prevalence of goitre(2).

Potential recruits for the Brigade of Gurkhas in the British Army come from several specific areas, which are mainly the foothills of the Himalayas. After medical checks during hill selection in November and December each year, approximately one thousand potential recruits without gross clinical abnormalities are sent for depot selection at two main centres, Dharan in the East and Pokhara in West Central Nepal (Fig 1). The *Now Consultant Physician, Queen Elizabeth Military Hospital, Woolwich, London SE18 4QH selection process demands a high degree of fitness therefore these are probably some of the fittest men in Nepal.

Kochupillai et al(3) measured the total thyroie hormones in blood from newborn babies in a subब Himalayan endemic goitre region in India and fount higher TSH, $\mathrm{T}^{3}$ and lower $\mathrm{T}^{4}$ compared to controls i New Delhi. The free thyroid hormones are the mos important in assessing the thyroid status of individualsi since these are the unbound, active hormones. In studies measuring the free thyroid hormones in the bloodo Chopra et al (4) measured thyroid hormone levels in non? goitrous subjects from New Guinea. The serum fT concentrations of these people were found to be lower $\mathrm{fT}^{3}$ and TSH concentrations were higher than normas controls in the US. These findings agree with IngenbleelN et al(5) who studied the free serum hormone levels intw, non-goitrous males from an endemic goitre area ig్ 
Senegal. Blood $\mathrm{fT}^{4}$ concentrations were lower, $\mathrm{fT}^{3}$ and TSH concentrations higher than in control subjects from Dakar, the capital.

The aims of this study were to measure serum free thyroid hormone concentrations in the potential Gurkha recruits, to discover if any subclinical iodine deficiency or thyroid dysfunction was present and to compare the results with those of normal UK recruits and the same men ten months later after basic training when they had an army diet in Hong Kong which is considered to contain sufficient iodine.

\section{Methods}

One thousand and five men between the ages of 17 and 22 years arrived at the depots in 1986. Goitre was excluded during the medical examination necessary for recruitment and $20 \mathrm{ml}$ blood samples were taken. Two hundred and forty-eight of the men were recruited into the army and urine samples $(20 \mathrm{ml})$ were collected from them. Twenty per cent of these men (53 subjects) were selected at random and underwent TRH stimulation tests.

After ten months basic training in Hong Kong repeat blood and urine samples were obtained. TRH stimulation tests were repeated on those subjects tested previously.

For comparison with the thyroid levels, blood samples from 186 UK Army recruits (male, age range 19-20 years) were analysed. These recruits had passed their preliminary medical examination and were healthy.

Blood samples were allowed to clot and were separated within a few hours of withdrawal. The serum and the urine samples were frozen at $-20^{\circ} \mathrm{C}$ for storage and transport. Serum samples were analysed in duplicate for $\mathrm{fT}^{3}, \mathrm{fT}^{4}$ and $\mathrm{TSH}$ using kits manufactured by Amersham International plc. 'Amerlex-M free $\mathrm{T}^{3}$ ' and 'Amerlex-M free $T 4$ ' are based on an analogue radioimmunoassay. The $\mathrm{fT}^{3}$ assay had a sensitivity of $0.15 \mathrm{pmol} / \mathrm{l}$ with an inter-assay coefficient of variation (CV) of $2.9 \%$ at $5.0 \mathrm{pmol} / \mathrm{l}$ and the $\mathrm{fT}^{4}$ assay had a sensitivity of $0.1 \mathrm{pmol} / \mathrm{l}$ with an inter-assay $\mathrm{CV}$ of $4.0 \%$ at $14.8 \mathrm{pmol} / \mathrm{l}$. The Amerwell TSH assay utilizes a one step immunoradiometric technique with monoclonal antibodies to produce a sensitivity of $0.04 \mu \mathrm{IU} / \mathrm{ml}$ with an inter-assay $\mathrm{CV}$ of $4.5 \%$ at $3.8 \mu \mathrm{IU} / \mathrm{ml}$.

The TRH stimulation tests were carried out as follows: serum from a baseline sample before injection of $200 \mu \mathrm{g}$ TRH and a second sample 30 minutes later were analysed for TSH.

Urine samples were analysed for iodine and creatinine using a method based on that of Garry et al(6). The Hong Kong army diet was analysed using a modified method of Moxon and Dixon(7).

Statistical significance of the differences in ${ }_{0} \overrightarrow{0}+\vec{T}$ concentrations between the groups was tested using a paired t-test for the same group in different years, and an unpaired t-test between different groups $(8)$. Due to difficulties in the sample transportation some records

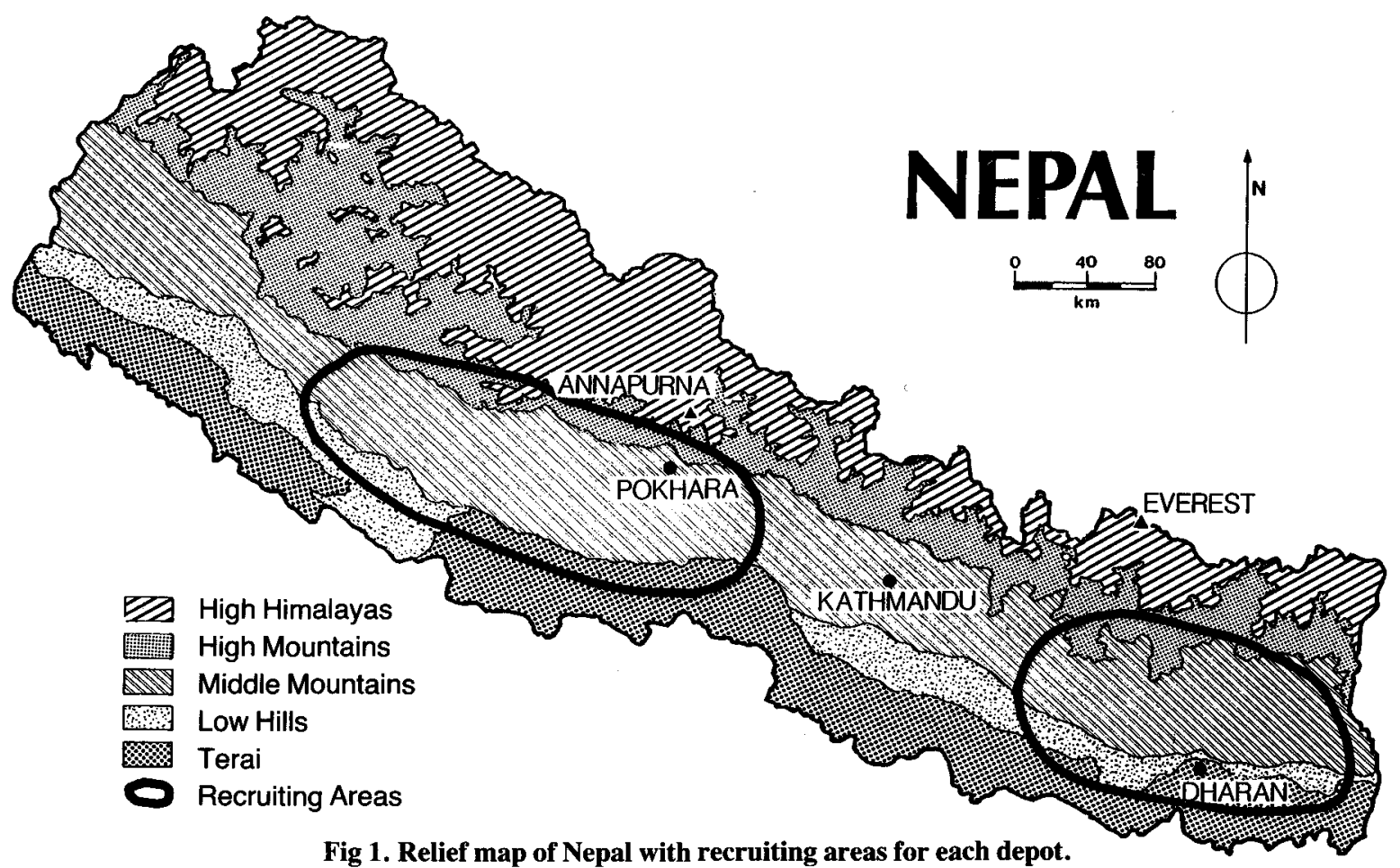

Fig 1. Relief map of Nepal with recruiting areas for each depot. 
were incomplete. Only those recruits having complete records of serum thyroid hormones or urine analysis were included in the study. Ethical permission was obtained where necessary from the UK Government and the Nepalese Ministry of Health.

\section{Results}

\section{Hormone concentrations of potential recruits}

The concentrations of $\mathrm{fT}^{4}$ and $\mathrm{fT}^{3}$ in the total group of potential Gurkha recruits in 1986 were significantly higher than those of the UK group (Table 1) and there was an elevation of TSH ( $<<0.001$ in all cases). The difference between the potential recruits in Nepal and the UK recruits becomes more apparent when represented graphically as a histogram (Fig 2).

There was no significant difference in $\mathrm{fT}^{3}$ concentrations between the East and West Nepal groups. However the mean $\mathrm{fT}^{4}$ concentration was significantly lower $(\mathrm{p}<0.025)$ and the mean TSH concentration was significantly higher $(p<0.001)$ in the West than the East group.

Hormone concentrations and urine analysis after basic training

The data in Table 2 show that after ten months of basic training and army diet the mean serum hormone concentrations of the whole group of recruited Gurkhas became similar to those of the UK recruits. The $\mathrm{fT}^{4}$ and TSH decreased to concentrations not significantly different from the UK recruits.

The $\mathrm{fT}^{3}$ concentrations also decreased but the values remained significantly different from the UK group. 3 These changes in serum hormone concentrations in $1987_{2}$ compared to the same groups in 1986 were statistically? significant $(p<0.001)$ except for the TSH concentration in the Dharan recruits which was unchanged. For the whole Gurkha group, the $\mathrm{fT}^{3}$ distribution was most affected by the change in diet, as shown graphically in Figure 3.

The results of the TRH stimulation tests in 1986 and 1987 are shown in Table 3 . The basal concentrations of TSH before, the peak concentrations after, and the total change of TSH in response to TRH were all lower incs 1987 than in 1986 and these differences were statistically ${ }_{\circ}$ significant for the total and for the Pokhara groups, butwere not significant in the Dharan group. The level ofw significance is higher in both these groups at the $30^{\circ}$ minute sample than at the base level.

The results of the urinary iodine and creatininen analyses for the 159 recruits having all tests carried ou in 1986 and 1987 are shown in Table 4. There was ar significant difference in urinary iodine $(\mathrm{p}<0.001)^{\circ}$. concentrations between the two areas, with the Dharan having significantly higher levels than the Pokhara groupo in 1986. In 1987 there had been a significant rise in the mean urinary iodine concentration of the whole grou 7 . Tा However this was entirely due to a rise in those from thineo Pokhara depot $(\mathrm{p}<0.001)$, as there was no significa change in values in the Dharan group. Dharan affu Pokhara were not significantly different from each otherin 1987.

Urinary creatinine concentrations were significan higher in Dharan than in Pokhara $(\mathrm{p}<0.005)$ in 1986. $\Phi$

Table 1

Thyroid hormone concentrations in potential Gurkha recruits and in U.K. recruits. (Mean values and standard deviations)

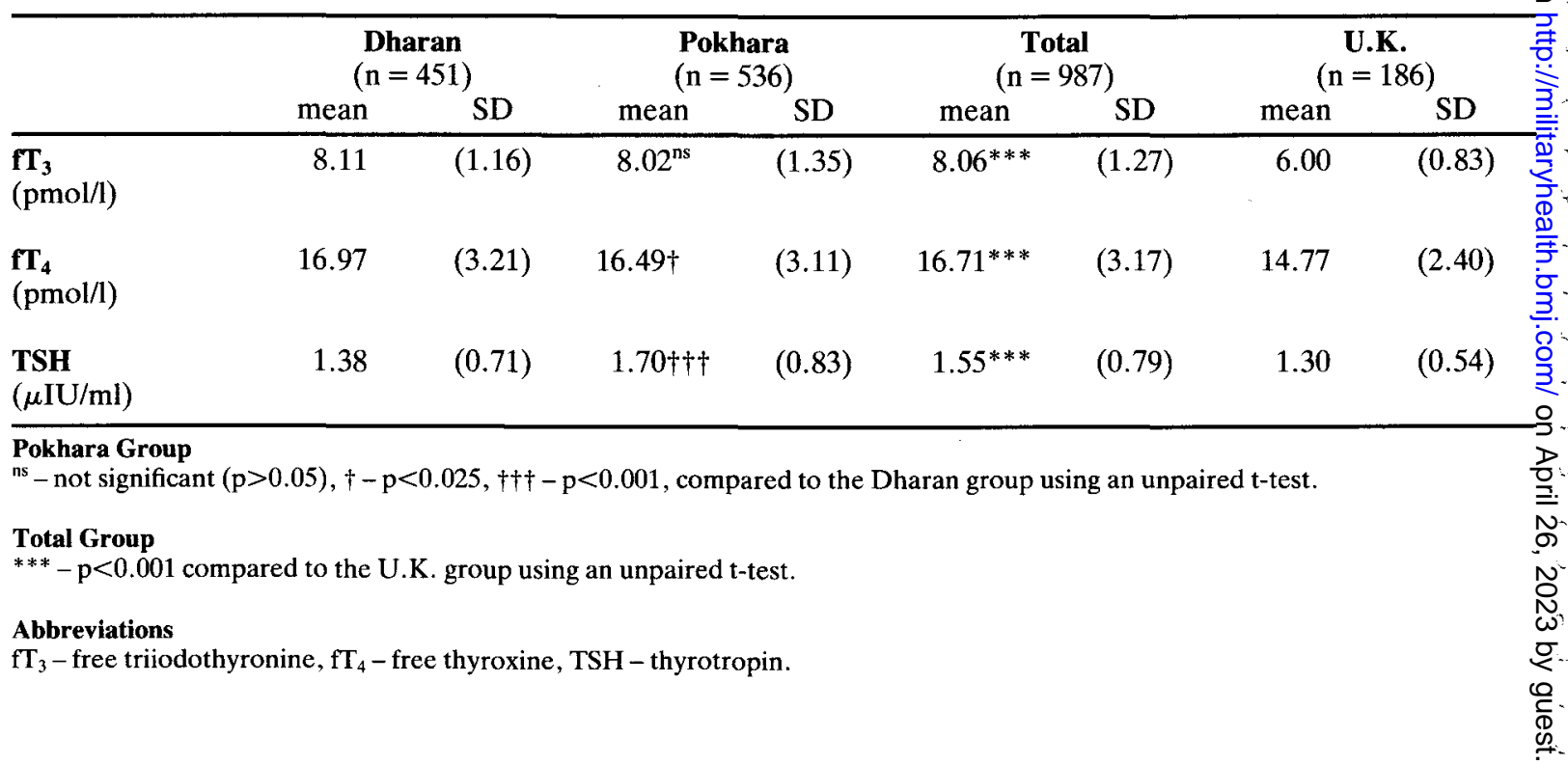


1987 they had both risen significantly $(\mathrm{p}<0.001)$ but the difference between them remained significant $(\mathrm{p}<0.025)$.

\section{Discussion}

The differences in $\mathrm{fT}^{3}$ and TSH concentrations in the potential Gurkha recruits are consistent with those from other iodine deficient areas; the slightly elevated concentrations of $\mathrm{fT}^{4}$ are not(9). They also differ from the results of other investigators $(4,5)$. However, one study carried out in Nepal found similar high blood total
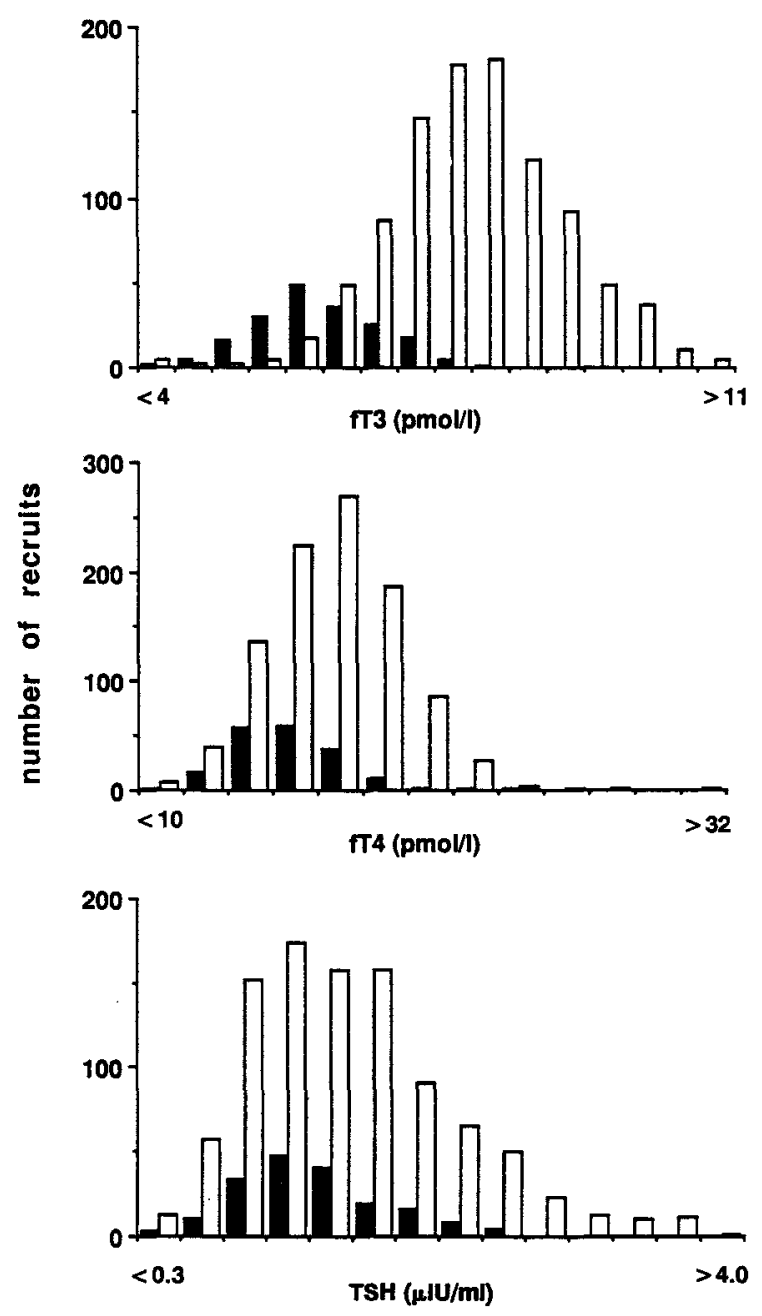

Fig 2. The distribution of thyroid hormones in serum of potential Gurkha $(\square)$ and U.K. recruits ( $\square$ ). The intervals are: triiodothyronine $\left(\mathrm{fT}_{3}\right)-0.5 \mathrm{pmol} / \mathrm{l}$; thyroxine $\left(\mathrm{fT}_{4}\right)-2 \mathrm{pmol} / \mathrm{l}$ and thyrotropin $(\mathrm{TSH})-0.3$ $\mu \mathrm{IU} / \mathrm{ml}$.
$\mathrm{T}^{4}$ concentrations(10). Although the patients in that study were goitrous, it was found that the group with low grade goitre had higher $\mathrm{T}^{4}$ than both those patients with more severe goitre and a control group in the UK. This was attributed to the controls coming from a different population, which also applies to our results.

Any obvious signs of malnutrition would preclude the men from the recruitment tests; however the potential Gurkha recruits were possibly both iodine deficient and relatively malnourished, with the Western Pokhara group exhibiting greater extremes. One study of
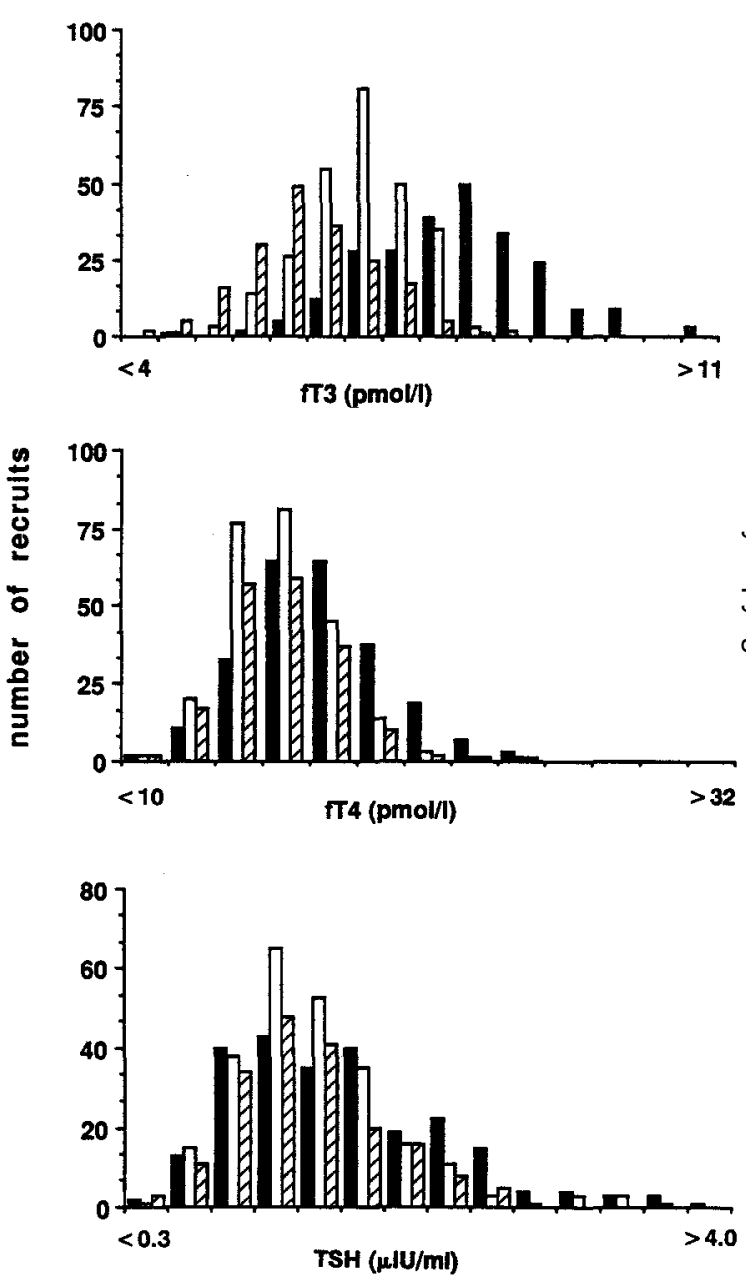

Fig 3. The changes in distribution of thyroid hormones in serum of Gurkha recruits before (1986) ( $)$ and after basic training (1987) ( $\square$ ). The distribution of the same hormones of U.K. recruits is shown for comparison (ZZ). The intervals are: triiodothyronine $\left(\mathrm{fT}_{3}\right)-0.5 \mathrm{pmol} /$; thyroxine $\left(\mathrm{fT}_{4}\right)-2 \mathrm{pmol} / \mathrm{l}$ and thyrotropin (TSH) -0.3 $\mu \mathrm{IU} / \mathbf{m l}$. 
Table 2

Results of blood thyroid hormone analyses of Gurkhas before recruitment and 10 months later, compared to $U$ K recruits. (Mean values and standard deviations).

\begin{tabular}{|c|c|c|c|c|c|c|c|c|}
\hline & \multicolumn{2}{|c|}{$\begin{array}{c}\text { Dharan } \\
(n=126)\end{array}$} & \multicolumn{2}{|c|}{$\begin{array}{l}\text { Pokhara } \\
(\mathrm{n}=118)\end{array}$} & \multicolumn{2}{|c|}{$\begin{array}{c}\text { Total } \\
(\mathrm{n}=244)\end{array}$} & \multicolumn{2}{|c|}{$\begin{array}{c}\text { U.K. } \\
(\mathrm{n}=186)\end{array}$} \\
\hline & mean & SD & mean & SD & mean & SD & mean & $\mathrm{SD}$ \\
\hline $\mathbf{f T}_{3}{ }^{\prime} 86$ & 8.07 & $(1.19)$ & $8.08^{\mathrm{ns}}$ & $(1.08)$ & $8.07^{* * *}$ & $(1.14)$ & \multirow{2}{*}{6.00} & \multirow[t]{2}{*}{$(0.83)$} \\
\hline $\begin{array}{c}\text { '87 } \\
(\mathrm{pmol} / \mathrm{l})\end{array}$ & $6.43^{\bullet \bullet \bullet}$ & $(0.60)$ & $6.32^{\mathrm{ns}}$ & $(0.67)$ & $6.38^{* * *}$ & $(0.64)$ & & \\
\hline $\mathrm{fT}_{4}{ }^{\prime} 86$ & 16.75 & $(3.12)$ & $16.49^{\text {ns }}$ & $(3.31)$ & $16.63^{* * * *}$ & $(3.21)$ & \multirow{2}{*}{14.77} & \multirow{2}{*}{$(2.40)$} \\
\hline $\begin{array}{c}\text { '87 } \\
(\mathrm{pmol} / 1))\end{array}$ & $15.06^{\bullet \bullet \bullet}$ & $(2.16)$ & $14.54^{\mathrm{ns}}$ & $(2.36)$ & $14.81^{\mathrm{ns}}$ & $(2.27)$ & & \\
\hline TSH '86 & 1.43 & $(0.70)$ & $1.71 \dagger \dagger$ & $(0.80)$ & $1.57^{* * *}$ & $(0.76)$ & \multirow{2}{*}{1.30} & \multirow{2}{*}{$(0.54)$} \\
\hline $\begin{array}{c}\text { '87 } \\
(\mu \mathrm{IU} / \mathrm{ml})\end{array}$ & $1.41^{\mathrm{nd}}$ & $(0.61)$ & $1.34^{\mathrm{ns}}$ & $(0.57)$ & $1.38^{\mathrm{ns}}$ & $(0.59)$ & & \\
\hline \multicolumn{9}{|c|}{$\begin{array}{l}\text { Pokhara Group } \\
\text { ns }- \text { not significant }(p>0.05), \uparrow \uparrow-p<0.005 \text {, compared to the Dharan group using an unpaired } t-t e s t .\end{array}$} \\
\hline \multicolumn{9}{|c|}{$\begin{array}{l}\text { Groups before and after recruitment } \\
\text { nd }{ }_{-} \text {not significant }(p>0.05), \cdots-p<0.001, \text { compared to the same group ten months earlier using a paired } \mathbf{t} \text {-test. }\end{array}$} \\
\hline
\end{tabular}

malnutrition in adults and children found that serum $\mathrm{fT}^{4}$ levels are elevated compared to controls of the same individuals after treatment(11). However at the same time serum $\mathrm{fT}^{3}$ levels are lower corresponding to an increase in $\mathrm{fT}^{3}$ and $\mathrm{TSH}$ levels are either slightly lower or unchanged. Other studies have found that $\mathrm{fT}^{4}$ is depressed in prolonged malnutrition(12).

Iodised salt has been distributed to the Nepalese people by the Government since 1972(13) and, in addition, a programme of iodised oil injection for mothers and children has been carried out by the Government of Nepal since 1979(1). Two studies of goitre patients before and after iodine prophylaxis found the free thyroxine index (FTI) elevated after the iodine treatment $(14,15)$. With the Gurkha recruits it is not possible to tell if this has influenced the blood hormone levels because no records are available. A separate investigation as to which recruits may have received iodised oil produced conflicting results. Some recruits may have had injections, others certainly did not. The length of time that the iodine injections are effective is also uncertain(16).

The amount of iodine in the diet of the recruits in Nepal in 1986 is unknown. The urinary iodine concentration is an indication of the dietary iodine content but not an absolute measure(17); however a large number of samples such as this does give a reasonably valid assessment $(17,18)$. The values in Table 4 indicate the levels are low, with those in the Western Pokhara group having lower levels than the Eastern Dharan group $(\mathrm{p}<0.001)$. Mild endemic goitre is prevalent at a daily excretion of $25-50 \mu \mathrm{g}$ iodine; below this level severe endemic goitre and cretinism occurs(18). Assuming an average daily urine excretion of 1.51 per day(19), none of the values for the potential recruits shown in Table 4 are below this critical level; the values are also higher for all the recruits in 1986 than those quoted by Thilly et al(20). This could be a measure of success of the iodine prophylaxis. The iodine/ creatinine ratio, which has been used for many years to estimate dietary iodine intake, is not valid in this case because the recruits were almost certainly undernourished in $1986(17,18)$, with the creatinine values in 1987 being very different from those in 1986. The elevated $\mathrm{fT}^{4}$ could be due to low rates of conversion to $\mathrm{fT}^{3}$ peripherally as a reflection of minor malnutrition. This is reversible as shown by the repeat studies after basic training. 
Table 3

The results of TRH tests carried out on recruits in 1986 and 1987. ( $\mu \mathrm{IU} / \mathrm{ml}$ TSH mean values and standard deviations).

\begin{tabular}{|c|c|c|c|c|c|c|}
\hline & \multicolumn{2}{|c|}{$\begin{array}{c}\text { Dharan } \\
(n=24)\end{array}$} & \multicolumn{2}{|c|}{$\begin{array}{c}\text { Pokhara } \\
(n=26)\end{array}$} & \multicolumn{2}{|c|}{$\begin{array}{c}\text { Total } \\
(n=50)\end{array}$} \\
\hline & mean & SD & mean & SD & mean & SD \\
\hline \multicolumn{7}{|c|}{ Basal concentration } \\
\hline 1986 & 1.40 & $(0.65)$ & $1.70^{\mathrm{ns}}$ & $(1.12)$ & 1.56 & $(0.92)$ \\
\hline 1987 & $1.27^{\text {nd }}$ & $(0.47)$ & $1.37^{\mathrm{ns}}$ & $(0.73)$ & $1.32^{\bullet}$ & $(0.62)$ \\
\hline \multicolumn{7}{|c|}{ 30' post TRH concentration } \\
\hline 1986 & 10.82 & $(4.84)$ & $11.38^{\mathrm{ns}}$ & $(6.02)$ & 11.11 & $(5.44)$ \\
\hline 1987 & $9.55^{\text {nd }}$ & $(4.13)$ & $9.44^{\mathrm{ns}}$ & $(5.05)$ & $9.49^{\bullet \bullet \bullet}$ & $(4.58)$ \\
\hline \multicolumn{7}{|c|}{ Change in TSH concentration } \\
\hline 1986 & 9.42 & $(4.48)$ & $9.68^{\text {ns }}$ & $(5.36)$ & 9.55 & $(4.91)$ \\
\hline 1987 & $8.28^{\text {nd }}$ & $(3.75)$ & $8.26^{\mathrm{ns}}$ & $(4.62)$ & $8.27^{\bullet \bullet}$ & $(4.18)$ \\
\hline
\end{tabular}

Pokhara Group

${ }^{\mathrm{n}}$ - not significant ( $\mathrm{p}>0.05$ ), compared to the Dharan group using an unpaired t-test.

Groups before and after recruitment

nd - not significant $(\mathrm{p}>0.05), \stackrel{-}{\bullet}<0.025,{ }^{\bullet}-\mathrm{p}<0.005,{ }^{\bullet \bullet}-\mathrm{p}<0.001$, compared to the same group ten months earlier using a paire 8 t-test.

Table 4

Urine analysis results of Gurkha recruits in 1986 and 1987. (Mean values and standard deviations).

\begin{tabular}{|c|c|c|c|c|c|c|c|}
\hline & & \multicolumn{2}{|c|}{$\begin{array}{l}\text { Dharan } \\
(n=76)\end{array}$} & \multicolumn{2}{|c|}{$\begin{array}{c}\text { Pokhara } \\
(\mathrm{n}=83)\end{array}$} & \multicolumn{2}{|c|}{$\begin{array}{c}\text { Total } \\
(n=159)\end{array}$} \\
\hline & & mean & $\mathrm{SD}$ & mean & SD & mean & SD \\
\hline \multirow[t]{2}{*}{$\begin{array}{l}\text { Iodine } \\
(\mu \mathrm{g} / 100 \mathrm{ml})\end{array}$} & 1986 & 26.64 & (19.83) & $13.67^{* * *}$ & $(13.10)$ & 19.87 & $(17.83)$ \\
\hline & 1987 & $24.63^{\text {nd }}$ & $(10.21)$ & $25.88^{\mathrm{ns}}$ & $(10.41)$ & $25.28^{\bullet \bullet \bullet}$ & $(10.30)$ \\
\hline \multirow[t]{2}{*}{$\begin{array}{l}\text { Creatinine } \\
(\mathrm{mg} / 100 \mathrm{ml})\end{array}$} & 1986 & 111.07 & $(70.32)$ & $81.78^{* *}$ & $(44.16)$ & 95.78 & $(17.83)$ \\
\hline & 1987 & $253.63^{\bullet \cdots \bullet}$ & $(100.79)$ & $217.21^{*}$ & $(85.39)$ & $234.62^{\bullet \bullet \bullet}$ & $(94.55)$ \\
\hline
\end{tabular}

\section{Pokhara Group}

${ }^{n s}$ - not significant $(p>0.05),{ }^{*}-p<0.025,{ }^{* *}-p<0.005,{ }^{* *}-p<0.001$ compared to the Dharan group using an unpaired t-test.

\section{Groups before and after recruitment}

nd - not significant $(p>0.05), \cdots-p<0.001$, compared to the same group ten months earlier using a paired $t-t e s t$. 
The Hong Kong army diet was shown to provide approximately $150 \mu \mathrm{g}$ iodine per day $(43-57 \mu \mathrm{g}$ from solid food). After ten months basic training the differences in urinary iodine concentrations between Eastern and Western groups had been corrected and the urinary creatinine concentrations of both groups had increased indicating improved nutritional status. The serum $\mathrm{fT}^{3}$, $\mathrm{fT}^{4}$ and $\mathrm{TSH}$ levels in the same men had changed to almost normal levels. Since the blood sampling was almost a year later the changes cannot be due to differences in seasonal variations of thyroid hormones reported by Pasquali et al(21). The $\mathrm{fT}^{4}$ and TSH in the serum of the whole group had fallen to values not significantly different to those of the U.K. recruits. In the case of the serum TSH, this was due to a fall in the Pokhara group only since the concentrations of the Dharan group were already significantly lower and did not change in 1987 . The mean $\mathrm{fT}^{3}$ concentration of the whole group was also lower after the change in diet but was still significantly different from that of the UK group.

The TRH test is a standard test of assessment of pituitary-thyroid function, measuring the pituitary secretion of TSH in response to an intravenous bolus of TRH. The data in Table 3 show the TSH concentrations in response to TRH were lower in 1987 than in 1986. However all values are within the normal limits(17), therefore the TRH tests on the recruits in 1986 and 1987 showed no evidence of dysfunction. In the Pokhara group the level of significance between 1986 and 1987 was greater at 30 minutes after TRH than for the base level, whereas that for the Dharan depot was unchanged. This test highlights the difference in iodine deficiency and nutrition between the East and West depots and shows that the TRH test is a more sensitive marker than the base serum TSH concentration.

In conclusion we have found that serum thyroid hormone concentrations in potential Gurkha recruits were higher than those of UK recruits. Analysis of urinary iodine and creatinine showed slight evidence of iodine deficiency and malnourishment, more pronounced in the recruits from the Western Pokhara depot of Nepal. This is reflected in the regional differences in serum hormones especially in the TSH concentration in the Western region, which was highlighted by the TRH stimulation tests. The same tests failed to find any dysfunction of pituitary-thyroid function in any of the recruits. A change in diet caused the serum hormone concentrations of the Gurkha recruits to fall to levels more closely resembling those of the UK recruits, showing that the differences were reversible. There were regional variations in response to diet within the group, once again more pronounced in the serum TSH and urinary iodine concentrations of the Western group.

\section{Acknowledgements}

We would like to thank SSgt M W Drake at the British
Military Hospital in Dharan, D E M Snell and D G Wailling at the Royal Army Medical College, Millbank, and Dr Ian Lumley and his staff at the Laboratory of the Government Chemist for the dietary iodine assays. We also thank the Ministry of Health of His Majesty's Government in Nepal for their co-operation.

\section{REFERENCES}

1. ACHARD T. Some aspects of iodine deficiency in Nepal. $\stackrel{\overparen{Q}}{\varrho}$ Trop Doct 1987; 17: 5-7.

2. Kochupillai N, Pandav C S. Iodine deficiency disorders in Nepal, current status, control measures and future? strategy. UNICEF 1985.

3. Kochupillai N, Godbole $M \quad M$, Pandav $C \quad s, \vec{\omega}$ Karmarkar M G, AhUJAR M M S. Neonatal thyroid status in the iodine deficient environment of the Sub- $\frac{0}{3}$ Himalayan region of India. In: Hall R, Kobberling, J, eds. के Thyroid disorders associated with iodine deficiency and $\vec{\omega}$
excess. New York: Raven Press, 1985: 61-67.

4. Chopra I J, Hershman J M, Hornabrook R W. Serum thyroid hormone and thyrotropin levels in subjects from endemic goitre regions of New Guinea. J Clin Endocrinol Metab 1975; 40: 326-333.

5. InGenbleek Y, LuYPaert B, De NAyer P H. Nutritionad status and endemic goitre. Lancet 1980; 1: 388-392.

6. Garry P J, Lashley D W, OWEN G M. Automat庄 measurement of urinary iodine. Clin Chem 1973; 19: 95 953.

7. Moxon R, Dixon E. Semi-automatic method for determination of total iodine in food. Analyst 1980; 105: 344-352.

8. SNEDECOR G W, Cochran W G. Statistical methods Ames, USA: Iowa State University Press, 1974.

9. Degroot L J, Reed Larsen P, Reretoff S, Stanbury J B. Physiology of the hypothalamus, pituitary and thyroid. In: Thyroid and its diseases. New York; John Wiley and Sons, 1984: 118-163.

10. Kochupillai N, Deo M G, Karmarkar M G, et al. $\overrightarrow{\vec{O}}$ Pituitary thyroid axis in Himalayan endemic goitre. Lancet 3 1973; 1: 1021-1024.

11. Medeiros-Neto G A. General nutrition and endemicz goitre. In: Stanbury J B, Hetzel B S, eds. Endemic goitre and endemic cretinism. New York: John Wiley and Sons, 1980: 269-283.

12. INGENBLEEK $Y$. Thyroid function in nutritional disorders. In: Delange $F$, Fisher D, Malvaux $P$, eds. Pediatric thyroidology. Basel: Karger, 1985: 345-368.

13. Kochupillai N, Rawalingaswami V, Stanbury J B. The present status of endemic goitre as a problem of the public $\overline{5}$ health: Southeast Asia. In: Stanbury J B, Hetzel B S, eds. Endemic goitre and endemic cretinism. New York: John $\varnothing$ Wiley and Sons, 1980: 101-121.

14. Lamberg B A, Haikonen M, Makela M, Jukkara A, 0 AXLESON E, Welin M G. Further decrease in thyroidal uptake and disappearance of endemic goitre in children after 30 years of iodine prophylaxis in the East of Finland. Acta Endocrinol 1981; 98: 205-209.

15. Boukis $M$ A, Koutras $D$ A, Souvatzoglou A, Evangelopoulou A, Vrontakis M, Moulopoulos S D. ? Thyroid hormone and immunological studies in endemic $\mathrm{W}$ goitre. J Clin Endocrinol Metab 1983; 57: 859-862.

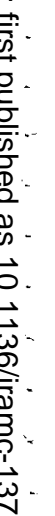


16. Maberly G F, Corcoran J M, Eastman C J. The effect of iodised oil on goitre size, thyroid function and the development of the Jod Basedow phenomenon. Clin Endocrinol 1982; 17: 253-259.

17. WERNER S C. The thyroid - a fundamental and clinical text. Philadelphia: JB Lippincott Company, 1986.

18. Bourdoux P, Delange F, Filetti S, Thilly C, Ermans A M. Reliability of iodine/creatinine ratio: a myth? In: Hall, R, Kobberling J, eds. Thyroid disorders associated with iodine deficiency and excess. New York: Raven Press, 1985: 145-152.

19. Brenner B M, Hostetter T H. Disturbances of renal function. In: Isselbacher K J, Adams R D, Brainwald E,
Petersdorf R G, Wilson J D, eds. Harrison's principles of internal medicine. McGraw-Hill International Book Company, 1980: 1286-1293.

20. Thilly C H, Bourdoux P, Swennen B, Bebe N, Due D, ERmans A M. Assessment and planning for IDD control programs. In: Hetzel B S, Dunn J T, Stanbury J B, eds. The prevention and control of iodine deficiency disorders. Holland: Elsevier Science Publishers B. V., 1987: 181-194.

21. Pasquali R, Baraldi G, Casimirri F, et al. Seasonal variations of total and free thyroid hormones in healthy men: a chronobiological study. Acta Endocrinol 1984: 107: $42-48$.

\section{REPORT OF A MEETING}

\section{ASSOCIATION OF SERVICE PHYSICIANS}

The eleventh annual meeting of the Association of Service Physicians was held at the Royal Army Medical College, Millbank, on 16 February 1990; forty nine members attended.

The Chairman for the first session was Air Commodore D H Hull, RAF Consultant Adviser in Medicine. Following an opening introduction and welcome by Major General I P Crawford, Commandant and Postgraduate Dean, Royal Army Medical College, Millbank, Surgeon Commander M L Cowley presented a paper on Thrombolysis in England, giving the results of a survey of district policies and treatment rates. Though thrombolytic therapy for acute myocardial infarction is now widely used, there is considerable variation in treatment rates, and a significant shortfall in the provision of this effective and life-saving treatment. In the second paper, Squadron Leader $\mathrm{N}$ A Harrison gave a very concise review of the use of various parameters for assessing disease progression in HIV-1 infection from asymptomatic carriage to the symptomatic state, and drew particular attention to the value of measuring Neopterin and Beta-2 microglobulin levels. In the third paper, Major M J World presented details of his experiences using intravenous Enoximone to treat patients with severe cardiac failure. This relatively new haemodynamic stimulant may be very beneficial, but its effects are sometimes pronounced, but not always entirely predictable or desirable, and he recommended very close haemodynamic and electrocardiographic monitoring if the agent is used.

The second session, with Surgeon Commander R H Taylor, Professor of Naval Medicine in the Chair, was devoted to Medical Audit in the Services. Major W M Melia, Wing Commander D J Rainford, and Surgeon Commander R J Clark gave reviews of the experiences of audit at the Queen Elizabeth Military Hospital Woolwich, the Renal Unit at Princess Mary's Hospital Halton, and the Royal Naval Hospital Haslar. These three very interesting and different presentations were followed by a stimulating discussion period, and the meeting concluded with lunch in the RAMC Headquarter Officers Mess.

T B N OLDREY 